\title{
Cystic Change in Pulmonary Tuberculosis in an Immunocompetent Adult: A Case Report ${ }^{1}$
}

\author{
Sung-Min Ko, M.D., Soo-Ji Seo, M.D. ${ }^{2}$, Won-Il Choi, M.D. ${ }^{3}$, Young-June Jeon, M.D. ${ }^{3}$
}

Cystic change associated with pulmonary tuberculosis is rarely encountered, and few reports are available on the radiologic findings of pulmonary tuberculosis presenting as multiple cystic lesions associated with consolidation or bronchohematogenous nodules. The cystic lesions in our pulmonary tuberculosis patient occurred during steroid treatment without antituberculous chemotherapy and progressively increased in size, but subsequently became smaller after the initiation of antituberculous chemotherapy. Herein, we report the chest radiographic and computed tomographic findings of cystic change in pulmonary tuberculosis in an immunocompetent adult.

\section{Index words : Lung}

Tuberculosis, cysts

Computed tomography $(\mathrm{CT})$, radiography

Cavitation in one or multiple sites occurs in about $50 \%$ of patients with postprimary tuberculosis (1). However, cystic change associated with pulmonary tuberculosis has rarely been reported in radiologic and pathologic studies (2- 4). According to these reports, cystic change developed before or during antituberculous chemotherapy in patients with pulmonary tuberculosis that initially presented with acute respiratory failure. Furthermore, these cystic lung lesions almost completely resolved with residual irregular lines after initiating antituberculous chemotherapy. We report a rare case of pulmonary tuberculosis with cystic change.

${ }^{1}$ Departments of Radiology, Konkuk University, Konkuk University School of Medicine, Korea

${ }^{2}$ Departments of Radiology and ${ }^{3}$ Departments of Internal Medicine, University of Keimyung College of Medicine, Dongsan Medical Center, Korea

Received August 9, 2007 ; Accepted November 9, 2007

Address reprint requests to : Sung-Min Ko, M.D., Department of Radiology, Konkuk University Hospital, Konkuk University School of Medicine, 4-12 Hwayang-dong, Gwangjin-gu, Seoul 143-729, Korea .

Tel. 82-2-2030-5578 Fax. 82-2-447-8726 E-mail: ksm9723@yahoo.co.kr

\section{Case Report}

A 48-year-old immunocompetent man was admitted to our hospital with shortness of breath. He complained of a febrile chilling sensation, a dry cough, and myalgia of duration 1 month. In particular, his symptoms were aggravated after applying paint to furniture 9 days previously. On admission, his body temperature was $36.8^{\circ} \mathrm{C}$, pulse rate 88 beats per minute, and respiratory rate 22 breaths per minute. Arterial blood gas analysis showed a $\mathrm{pH} 7.472$, Pco2 of $25.6 \mathrm{mmHg}$, and a Po2 of $36.0 \mathrm{mmHg}$. His white blood cell count was $4,880 / \mathrm{mm}^{3}$. Initial chest radiography (Fig. 1A) and thin-section CT (Fig. 1B) showed diffuse bilateral areas of ground-glass opacity and disseminated micronodules in both lungs with loculated chronic right pleural effusion. On the second day of his hospitalization, dyspnea and hypoxemia were severely aggravated. Accordingly, he was transferred to the intensive care unit (ICU) and received mechanical ventilation for 4 days. This acute respiratory failure was believed to be associated with hypersensitivity pneumoni- 


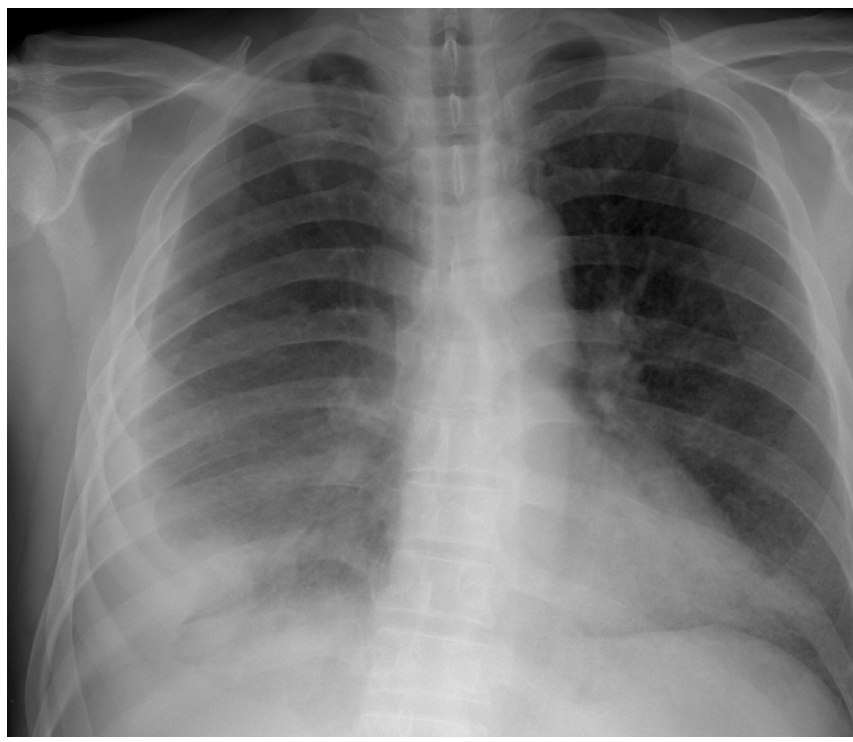

A

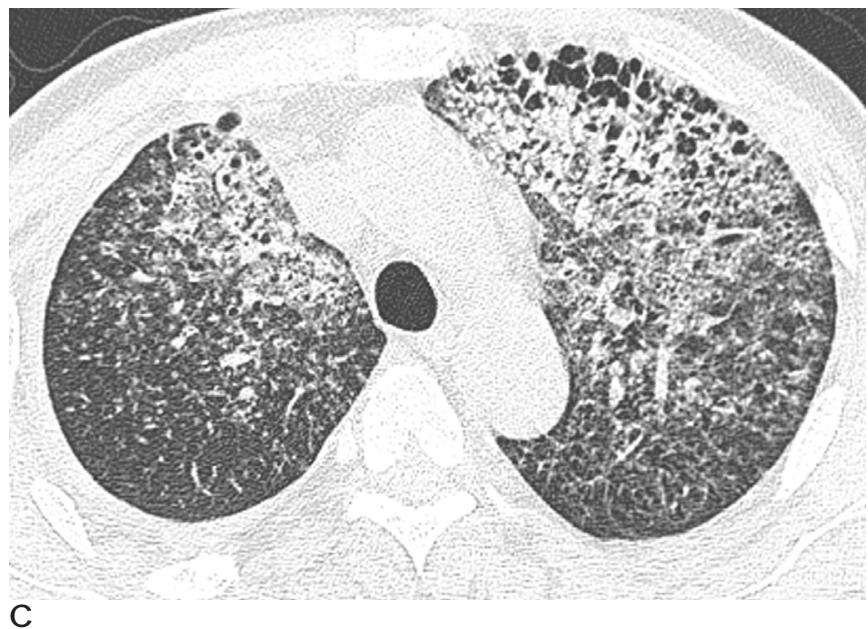

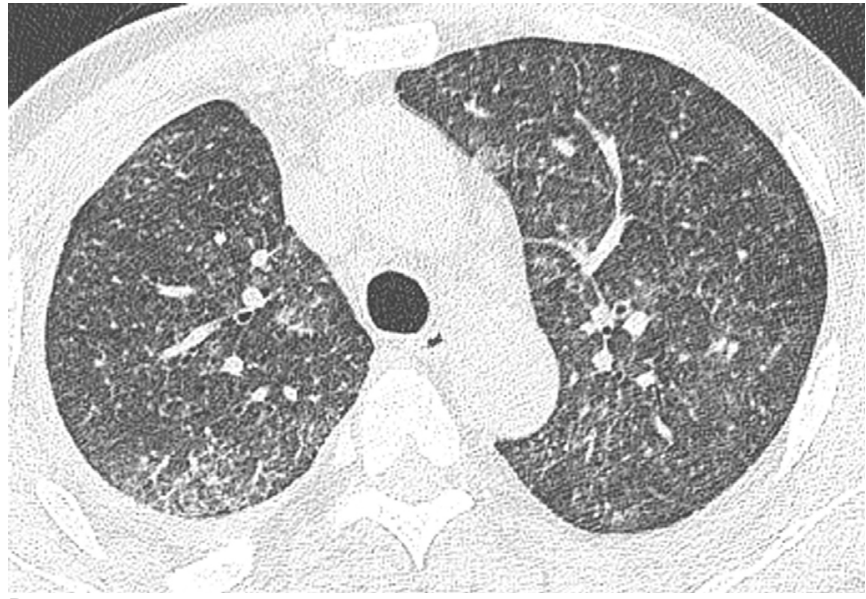

B

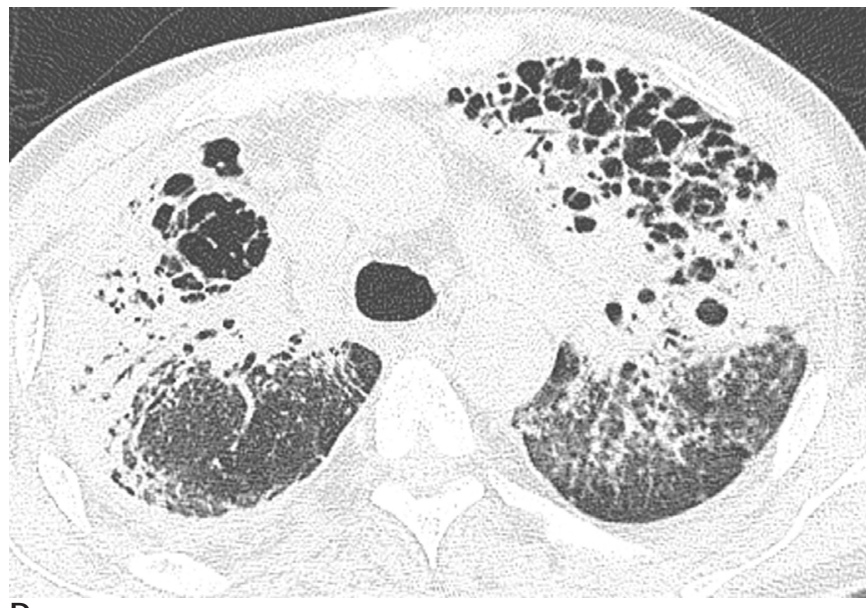

D

Fig. 1. Cystic change in pulmonary tuberculosis in a 48-year-old man.

A. Initial chest radiograph shows diffuse bilateral areas of ground-glass opacity and disseminated micronodules in both lungs and loculated chronic right pleural effusion.

B. Thin-section CT scan obtained at the same time as (A) shows diffuse ground-glass opacity and widespread micronodules in both lungs. These CT findings suggest subacute hypersensitivity pneumonitis or miliary tuberculosis with acute respiratory distress syndrome.

C. Thin-section CT scan obtained 2 weeks after admission shows patchy areas of ground-glass opacity and consolidation with cystic lesions in both upper lobes, but predominantly in the anterior segment of the left upper lobe.

D. Thin-section CT scan performed 40 days after admission shows marked increases in the sizes and numbers of cystic lesions and areas of consolidation in both lungs as compared the CT scan performed at 2 weeks $(\mathbf{C})$.

E Thin-section CT scan obtained 6 month after admission shows that the cystic lesions decreased markedly and tended to coalesce. Areas of consolidation disappeared near completely leaving areas of fibrotic change in both upper lobes. 
tis, and so steroid treatment was started. While the patient was being treated with steroid (prednisolone 125 mg daily) in the ICU for 6 days, his vital signs and radiographic manifestations improved, and he was returned to a general ward on steroid treatment (prednisolone $60 \mathrm{mg}$ daily) for 6 days. However, fever re-developed and ground-glass opacity and nodular opacities increased in extent in both lungs on a follow-up chest radiograph performed 2 weeks after admission (not shown). Thin-section CT (Fig. 1C) showed patchy areas of ground-glass opacity and consolidation with cystic lesions in the both upper lobes. Results of smear and culture of sputum and bronchoalveolar lavage (BAL) fluid were positive for acid-fast bacilli, and polymerase chain reaction for tuberculosis was positive in BAL fluid. However, BAL fluid was negative for Pneumocystis jiroveci. The steroid treatment was discontinued and antituberculous medication (isoniazid, rifampin, ethambutol hydrochloride, and pyrazinamide) was started. However despite antituberculous chemotherapy for 2 weeks, he had a continuous fever. Follow-up chest radiography performed 40 days after admission showed increased extent with cystic lesions in both lungs (now shown).

Thin-section CT (Fig. 1D) revealed that cystic lesions had increased in size and number and areas of consolidation with cysts increased in extent in both lungs at the sites of previous ground glass opacity and consolidation with cysts. Accordingly, streptomycin and ciprofloxacin were added. Thin-section CT (Fig. 1E) performed 6 months after admission showed that cystic lesions had markedly decreased in extent and residual fibrotic areas in both upper lobes.

\section{Discussion}

On high resolution $\mathrm{CT}$, lung cysts are thin-walled, well-defined and circumscribed, air-or fluid-containing lesions (5). Multiple pulmonary cysts are noted in Langerhans cell histiocytosis (6), lymphangioleiomyomatosis (7), lymphocytic interstitial pneumonia (8) and infectious diseases, such as, Pneumocystis jiroveci pneumonia (9). However, cystic changes associated with pulmonary tuberculosis have rarely been reported in radiologic and pathologic studies (2- 4), although cystic changes have been reported after isoniazid treatment in pulmonary tuberculosis in human and experimental animal studies (10). Most of the reported cases occurred in disseminated pulmonary tuberculosis like our case. In a pathologic report of cystic change in an immuno- compromised patient with pulmonary tuberculosis, multiple cystic lesions were suggested to be associated with a check-valve mechanism due to granulomatous involvement of bronchioles and the excavation of caseous necrotic material by draining bronchi (4). In the case report issued by Ko et al. (2), multiple air-filled cystic lesions developed before or during antituberculous medication in three immunocompetent patients with pulmonary tuberculosis who initially experienced acute respiratory failure and diffuse bilateral pulmonary opacity depicted by admission chest radiography. Moreover, these cystic lesions disappeared almost completely leaving residual irregular lines after antituberculous therapy.

In the described case, the patient was misdiagnosed as having subacute hypersensitivity pneumonitis instead of miliary tuberculosis with acute respiratory distress syndrome. Accordingly, he was treated with steroid for 2 weeks without antituberculous chemotherapy, and thin-section CT performed 2 weeks after admission showed patchy areas of ground-glass opacity and consolidation with multiple thin-walled cystic lesions in both upper lobes. Despite antituberculous chemotherapy for 2 weeks, these cystic lesions increased in size and number on follow-up CT. However, they gradually subsided and showed a tendency to coalesce on follow-up CT after antituberculous chemotherapy had been initiated. These imaging features are in accord with those of previously reported cases (2). Our patient was mechanically ventilated for 4 days, and cystic lesions in our patient were similar to air cysts and bronchiectasis that are usually correlated with prolonged ventilation in patients with severe acute respiratory distress syndrome (11). However, in our case these cystic changes were not associated with mechanical ventilation, because air cysts developed after recovery from acute respiratory failure and were markedly increased in size and number during antituberculous chemotherapy. In addition, his vital signs and radiographic manifestations improved after 4 days of mechanical ventilation.

Pulmonary tuberculosis with cystic change must be differentiated from other cystic lung diseases as abovedescribed. As compared with pneumatocele in Pneumocystis jiroveci pneumonia, cystic change in pulmonary tuberculosis develops in areas of bronchohematogenous nodules and consolidation in patients who initially present with acute respiratory failure, and almost heal entirely after administering antituberculous chemotherapy. In the proper clinical context, cystic 
change in pulmonary tuberculosis can be easily diagnosed.

In summary, the cystic lesions in our patient with pulmonary tuberculosis occurred during steroid treatment without antituberculous chemotherapy. They then progressively increased in size, but became smaller after commencing antituberculous chemotherapy. In the proper clinical context, cystic change in pulmonary tuberculosis can be easily differentiated from various other cystic lung diseases.

\section{References}

1. Im JG, Itoh H, Lee KS, Han MC. CT-pathology correlation of pulmonary tuberculosis. Crit Rev Diagn Imaging 1995;36:227-285

2. Ko KS, Lee KS, Kim Y, Kim SJ, Kwon OJ, Kim JS. Reversible cystic disease associated with pulmonary tuberculosis: radiologic findings. Radiology 1997;204:165-169

3. Cai HR, Cao M, Meng FQ, Li WC. Cystic changes associated with pulmonary tuberculosis: a case report. Chin Med J 2006;119:11251128

4. Takemura $\mathrm{T}$, Akiyama $\mathrm{O}$, Yanagawa $\mathrm{T}$, Ikushima $\mathrm{S}$, Ando $\mathrm{T}$,
Oritsu M. Pulmonary tuberculosis with unusual cystic change in an immunocompromised host. Pathol Int 2000;50:672-677

5. Naidich DP. High-resolution computed tomography of cystic lung disease. Semin Roentgenol 1991;26:151-174

6. Sundar KM, Gosselin MV, Chung HL Cahill BC. Pulmonary Langerhans cell histiocytosis: Emerging concepts in pathology, radiology, and clinical evolution of disease. Chest 2003;123:16731683

7. Sherrier RH, Chiles C, Roggli V. Pulmonary lymphangioleiomyomatosis. CT findings. AJR Am J Roentgenol 1989;153:937-940

8. Ichikawa $Y$, Kinoshita M, Koga T, Oizumi K, Fujimoto $K$, Hayabuchi N. Lung cyst formation in lymphocytic interstitial pneumonia: CT features. J Comput Assist Tomogr 1994;18:745-748

9. Feuerstein IM, Archer A, Pluda JM, Francis PS, Falloon J, Masur $\mathrm{H}$, et al. Thin-walled cavities, cysts, and pneumothorax in Pneumocystis carinii pneumonia: further observations with histopathologic correlation. Radiology 1990;174:697-702

10. Fernandez A, Shah MD, Buhariwalla RJ. Multiple isoniazid cysts in a child with chronic pulmonary tuberculosis. Indian Pediatr 1972;9:49-50

11. Treggiari MM, Romand JA, Martin JB, Suter PM. Air cysts and bronchiectasis prevail in nondependent areas in severe acute respiratory distress syndrome: a computed tomographic study of ventilator-associated change. Crit Care Med 2002;30:1747-1752

\title{
면역기능 정상인 성인 환자에서 폐결핵의 낭성변화에 대한 증례보고 ${ }^{1}$
}

\author{
${ }^{1}$ 건국대병원 영상의학과 \\ ${ }^{2}$ 계명의대 동산의료원 영상의학과 \\ ${ }^{3}$ 계명의대 동산의료원 호흡기내과 \\ 고성민. 서수질. 최원일. 전영준 ${ }^{3}$
}

폐결핵과 관련된 낭성변화는 매우 드물다. 기강경화나 기관혈행성 결절들과 관련된 다수의 낭성병변으로 나타나는 폐결핵의 방사선학적 소견에 관한 보고는 몇 편 되지 않는다. 우리 증례에서 환자의 낭성병변들은 항결핵제 치료 없이 스테로이드 치료를 받는 동안 생겼고, 항결핵제 치료 도중 낭성병변들은 크기가 커졌다가 감소하였다. 이에 저자들은 면역기능 정상인 성인 환자 폐결핵의 낭성변화에 대한 단순흉부 X- 선 소견과 전산화단층 소견을 문헌고찰과 함께 보 고하고자 한다. 